\title{
CONSTITUTIONAL ACCOMMODATION AND THE RULE(S) OF COURTS
}

\author{
LORNE SOSSIN
}

Constifutional authority for the development and implementution of the rules of court lies with both the legislature, by its statufory power, and the judiciary: by the constitutional principles of judicial independence. The court rules in question herc are those that govern court accessibility as well as the roles and responsibilities of parties in civil litigation. The three existing models of rule-making are courtled. where a majorin of government officials, and collaborative, which lacks an evident majority of either. These rule-making bodies do not control court fees. the executive does. but in a system with any model. the judiciary always has the final say in interprefing and implementing the rules or fees of the court. This creates on unavoidable conflict between the government and the judiciary.

The relevant principles of judicial independence in shis conflict are the inherent powers of the courts to control all aspects of judicial function, as well as the necessity of accessibility to the courts. The integrity of the administration of justice requires a constitutional compromise that respects these principles and creates an interdependent balance benveen the judiciary and Parliament. An independent commission composed of non-judicial, non-governmental mediators where dispwtes benween the courts and the governments may' be brought would support this requirement. Such a commission would instill the necessary confidence in both parties, and would facilitate an effective collaborative guardianship over the administration of court rules and fees while preserving the constitutional principles.
L autoriti constitutionnelle pour le developpemom et la mise en oewre des règles de procidure repose atuprès de la législature, de par son pouvoir légal, et atuprès de lordre judiciaire, de par les principes constilutionmels d'indépendance judiciaire. Les règles de la cour remises en question som celles qui régissent l'accessibilité à la cour ainsi que les roles et les responsabilités des parties d'un procès civil. Les trois modèles d'établissement de règles existan's sont menés par le tribunal, où une majorité de roprésentanis du gowvernement. el collaboratif qui " a pas de vraie mojorité. Ces organismes voiem $\dot{a}$ l'élablissement de rigles, mais ne contrilent pas nos droils de greffe car, c'est l'autorik exécutive qui y' voit. Mois dans un système dolé d'un modele. l'ordre judiciaire a le dernier mot en ce qui a trait à l'interprétation et à la misc en oenure des regles el des frais judiciaires. Cela crée inevitablement un conflit entre le gowvernement et l'ordre judiciaire. Dans ce conflit, les principes d'independance judiciaire pertinents sont les powvoirs inhérenis des tribunanux de controler tous les aspects de la fonction judiciaire, ainsi que te besoin daccessibilite alux tribunaux. $L$ intégrite de l'administration de lajustice" exige un compromis constifutionnel qui respecic ces principes et crie un équilibre interdcpendant entre l'ordre judiciaire et le Parlement. Une commission independante constituée de mediateurs non judiciaires ef non gouvernementaux, oì des disputes entre les tribunaux et les gowvernements peuvent ètre présentics répondrait à ce besoin. En outre, une telle commission accorderail la confiance voulue aux deux parties of faciliterait une tutelle en parficipation applicable sur ladministration des dicisions judiciaires ef less droits de greffe, touf en respectant les princupes constiturionnels.

TABLE OF CONTENIS

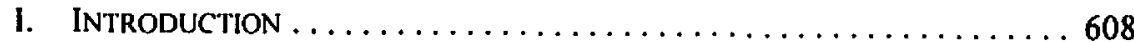

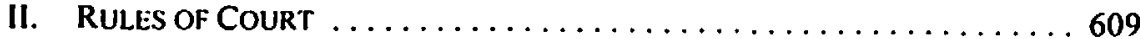

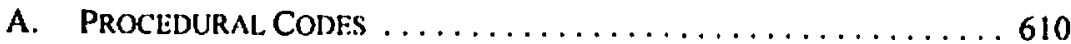

Faculty of Law, University of Toronto. I wish to thank Carl Baar, Bob I lann, Karim Benheklef and Fabien Getinas for their insights and Garry Watson for his constructive criticisms. An earlier version of the paper was presented to a faculty seminar at the Faculty of Law, University of Toronto and I am grateful for the many help ful suggestions of those who attended. Finally. I wish to acknowledge the superb research assistance provided by Amanda Gibson. 


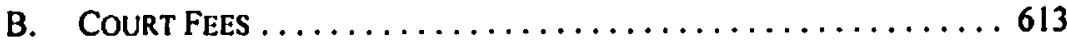

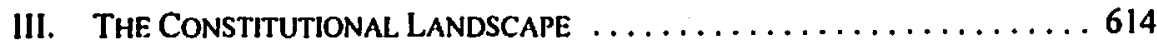

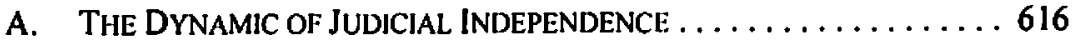

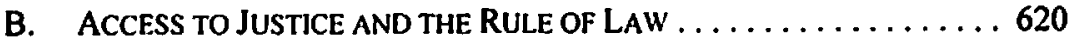

IV. THE THEORY AND PRACTICE OF

CONSTITUTIONAL ACCOMMODATION . .................6. 625

A. THE FinAl. ARBITER? CONSTITUTIONAL ACCOMMODATION THROUGH REMUNERATION COMMISSIONS .............. 627

B. CONSTITUTIONAL ACCOMMODATION THROUGII

INTERDEPENDENCE .......................6.630

\section{INTRODUCTION}

In this article, I ask what ought to be a simple question: who has constitutional authority for the development and implementation of the rules of court, and what are the limits, if any, on that authority. There are two simple answers, neither of which is on its own satisfactory, and each of which is difficult to reconcile with the other. The first answer is that it falls to the constitutional principles of the supremacy of Parliament and ministerial responsibility in a Westminster system to govern courts and their jurisdiction and processes. In other words, legislators have the final say in enacting statutes that demarcate the scope and powers of various courts, including the rules by which those courts are governed. The Attorney General, in turn, has supervision over the running of the courts and is responsible to the legislature for how the court budget is spent. The second answer is that the constitutional principles of judicial independence and access to justice require the courts to have ultimate supervisory authority over their own jurisdiction and processes. In other words, even if rules may come in the form of legislation or regulation, and even if court staff nominally report to the Attorney General, courts have functional control over the rules by which they are governed. Thus, the simple answer is that both the legislature and the judiciary have final authority over the rules of court. This kind of simple answer, of course, simply begs more complex questions.

If both Parliament and the courts arguably have final authority over changes to court rules (which I take to include, as discussed below, court fees), then how are disputes, if they arise, to be resolved, and the boundaries between political, administrative and judicial decisionmaking to be clarified? I suggest that it is in such settings that the only way forward, in both a principled and pragmatic sense, is constitutional accommodation and institutional interdependence. Constitutional accommodation will turn on a variety of factors and does not lead to one-size-fits-all solutions. Rather, it suggests a spectrum of possibilities for dealing with the relationship between government and courts across a range of functions and issues. That a mechanism of collaboration is appropriate for determining changes to the rules of civil procedure does not suggest this same mechanism is best suited to collaborating in the setting of court fees. It is to the need for and the nature of this spectrum of constitutional accommodation that I wish to devote the following brief analysis.

I believe this topic has never been of more urgent concern. Governments are under unprecedented pressure to ensure access to the courts, modernize court administration and find savings in the justice system. Courts are under unprecedented pressure to do more with 
less and to preserve the best interests of the justice system while remaining out of the political fray. The spectacle of showdowns between Chief Justices and Attorneys General over courthouse closures, budgets, building safety, labour relations, security and information technology, library facilities and even parking, has led to a proliferation of litigation and threats of litigation, adversarial posturing and an erosion of trust and confidence in the systems of court governance now in place in Canada.' There is a pressing need for a collaborative and effective means of bridging the constitutional divide between the governmental and the judicial responsibilities over maintaining and running courts. The time is thus ripe for a reappraisal of the place of court administration in Canada.

This analysis is divided into three sections. In the first section, I briefly explore the scope and content of rules of court, a term without a clear definition, and the current institutional forms through which those rules are developed. In the second section, I examine the constitutional principles and doctrines that apply to the rules of court and demonstrate the tensions and interdependence between courts, executive and legislative institutions in relation to courts. Finally, in the third section, $I$ argue for a framework of constitutional accommodation to resolve the puzzle of who has the last word in terms of rules of court.

\section{RULES OF COURT}

The rules of court regulate the practice and procedure of litigation and perform a gatekeeping function in terms of access to justice. I am here concerned specifically with civil courts, although many of the same issues and principles arise in the criminal justice system as well (and often with graver consequences at stake in the proceedings). ${ }^{2}$ Court rules may come in different forms; they may be legislative (set out in statutes such as the Courts of Justice Act), in regulations (such as the Rules of Civil Procedure, or Court Tariffs, etc.) or administrative (Practice Directions, Notices to the Profession, administrative guidelines, etc.); they may be issued by the Court or by the executive; they may emanate from rules committees, the office of a Chief Justice or the Ministry of the Attorney General; they may apply to various courts or just one, to all parties or just some.

What I term the court rules cover, in short, access to courts and the roles and responsibilities of parties once in the civil litigation system (including court-annexed or mandatory mediation, case management, court fees and other facets of court administration with a direct impact on civil litigation). While this definition is broader than most traditionally given to the rules of court (which would leave out, for example, court fees), it is not intended to capture every aspect of court administration. I wish to distinguish the rules of court from the more general questions regarding court administration, such as who

1 See Cristin Schmitz "Superior court judges seeking substantial pay raise: control over court administration" The Lainyers Weekly" (29 August 2003) I

$=\quad$ In the Criminal Code. R.S.C. 1985, c. C.46, courts are given express delegaled authority to issut rules. Section 482(1) of the Criminal Code provides.

Every superior court of criminal jurisdiction and every court of appeal may make rules of court not inconsistent with this or any other Act of Parliament, and any rules so made apply to any prosecution, proceeding. action or appeal, as the case may be, within the jurisdiction of that court, instituted in relation to any matter of a criminal nature or arising from or incidental to any such prosecution, procecding, action or appeal. 
controls the court budget, who controls the hiring and firing of court staff and who controls the building and maintenance of courthouses and judicial facilities (including security, information technology, judicial libraries and so forth), although court administration generally and the rules of court specifically are clearly interrelated. ${ }^{3}$

\section{A. Procedural Codes}

Every jurisdiction in Canada has legislation setting out the scope and jurisdiction of courts, and it is usually as regulations to such statutes that codes of civil procedure are enacted, which in turn make provision for courts to issue practice directions or otherwise issue what amounts to delegated regulations regarding the conduct of court (these often relate to registrar matters such as listing for trial but can also contain significant policy changes, such as the creation of the commercial list in Ontario). ${ }^{4}$ Procedural codes usually will set out the scope of litigation (for example, rules relating to joinder, intervention, consolidation, etc.), the method of litigation (for example, by application or action) and the conduct of litigation (for example, mandatory mediation, case management, simplified procedure, service and discovery, pleadings and examination, trials and appeals, motions and costs). ${ }^{5}$ As former Justice John Morden has written, "without fair and effective procedural law there cannot be substantive justice." 0

Every jurisdiction in Canada also has a body - usually designated as a rules committee - that makes recommendations regarding changes to the rules. Beyond this shared general approach, the institutional landscape for developing and implementing procedural rules varies considerably, ${ }^{7}$ and flows from variations in historical development, legal culture and statutory priorities. ${ }^{8}$ I wish to classify supervision over rule-making into three broad categories based on the makeup of such committees: (i) court-led, (ii) executive-led and (iii)

This more general category of questions about court administration also has no simple answer. While all Canadian jurisdictions are governed by a variation on the "executive model" whereby the Allorney Gencral is ultimately responsible for court administration, innovations have seen a delegation of portions of that authority to the judiciary to govern various aspects of court administration or have various levels of input in budgetary and administrative decision-making. Finally, as discussed below in relation to R. v.Valente, [1985]. 2 S.C.R. 673 [Valente]. there is a calegory of court administration which, as a matter of constitutional principle, must remain under judicial control, covering such matters as the setting of trial lists.

$+\quad$ Sec e.g. practice direction relating to Ontario's Rules of Civil Procedure, r. 48, "Listing for Trial," in James J. Canhy, M.A. Derry Millar \& Jeffrey G. Cowan, Ontario Anmual Practice 2003-200t (Toronto: Emond Montgomery, 2003). See also Commercial List Practice Direction (1995), 24 O.K. (3d) 455. discussed in Gary Watson et al., eds., The Civil Litigation Process: Cases and Materials, 5th ed. (Toronto: Emond Montgomery, 1999).

3 Not all procedural law is set out in these procedural codes. For example, both Ontario and B.C. enacted scparate class action acts to govern the procedures applicable to certifying and litigating class actions.

" John Morden, "An Overview of the Rules of Civil Procedure in Ontario" (1984) 5 Advocates Q. 257 at 264.

7. I am grateful to the Canadian Forum on Civil Justice for making available to me their survey on rule making across Canada. A summary of this survey was published as "Cross-Country Snapshot of Rules \& Rules Committees" News \& V'iews on Civil Justice Reform 5 (Fall 2002) 15, online: Canadian Forum on Civil Justice <inww.cfcj-fcjc.org/issue_5/n5-transcan.thm>.

* See the discussion of the history of court rules and the influence of English and American practice in Canada in Watson et al, supra note 4. 
collaborative, taking into consideration both the statutory provisions that establish or guide the work of rules committees and the actual practices of those committees.

In some Canadian settings, the court-led model of rule-making is apparent both in practice and in design. Importantly, even under the court-led model, the judicial involvement in rulemaking derives it legitimacy from a statutory mandate. For example, the Supreme Court ACt ${ }^{9}$ stipulates that amendments to the Rules must be signed by a majority of the Court (in other words, five judges) and marked with a stamp of approval under the Statutory Instruments $A c{ }^{10}$ by the Regulations section of the Department of Justice. The amendments must then be registered by the Clerk of the Privy Council and published in the Canada Gazette. In practice, the Supreme Court Rules Committee (which consists of three Supreme Court judges) consults directly with members of the Court, court staff, counsel and other groups. The Federal Court of Canada Rules Committee, also a statutory body," by contrast includes membership from the federal courts (trial and appellate), a member from the Courts Administration Service and five members of the Bar (as designated by the Attorney General). ${ }^{12}$

Saskatchewan has adopted a variation on this court-led theme. There, pursuant to the The Queen's Bench Acl, 1998, ${ }^{3}$ the Queen's Bench Rules Committee is composed of the Chief Justice, several Queen's Bench judges and the Registrar. Amendments approved by the rules committee are forwarded to a joint committee of the Law Society and the Saskatchewan branch of the Canadian Bar Association for comment. Following this consultation, the proposed amendments must be adopted by a majority of the Queen's Bench judges at an en banc meeting.

The court-led model is thus characterized by a majority of judicial members on a rules committee and a statutory process for enacting the proposals of the committee, which permits a minimal role, if any, for the executive and legislative branches. Whether or not the rules require the imprimatur of the executive (in the form of regulations) or the legislature (in the form of legislative amendments), the control in this model resides with the court.

By contrast, the executive-led model of rule-making reverses this equation and is characterized by executive leadership and accountability and usually provides mere consultation (sometimes mandatory, sometimes optional) with the judiciary. For example, in British Columbia, the Court Rules $\mathrm{Act}^{14}$ provides that the Lieutenant Governor in Council has authority over court rules. The Lieutenant Governor makes rules on the recommendation of the Attorney General who in turn consults with the Chief Justice of British Columbia. The Attorney General also appoints members of the rules committee, again following consultation with the court. In New Brunswick, while the Law Society has struck an ad hoc rules

R.S.C. 1985, c. S-26, s. 97.

R.S.C. 1985. c. S-22.

Federal ('ourl Acr, S.C. 1990, c. 8, s. 45.1

An analogous format is used for the rules committec of the Tax Court of $C$ anada. which includes the Chief Judge and Associate Chief Judge of the tax coun, two judges of the court, one representative of the Attorney General and two lawyers designated by the Attorney (ieneral.

S.S. 1998, c. Q.1.01, s. 28.

R.S.B.C. 1996, c. 80. 
committee to provide input on major initiatives, the Department of Justice legislative drafting branch has exclusive authority to draft rules of court.

Finally, there is the truly mixed model of rule-making, which is characterized by a shared mandate between courts and government and no obvious control by one branch over the priorities and preferences of the other. This collaborative model often is characterized by a significant presence of parties or groups that are neither governmental or judicial, but instead represent the Bar or the public at large. Ontario falls into this camp, in part because of the size of its rules committee ( 29 in total, including 16 judges, 11 lawyers ( 2 of whom are from the Attorney General) and 2 court administrators). Rules in Ontario typically are drafted by legislative counsel, approved by the rules committee, reviewed and passed by Cabinet and published, like other regulations, in the Ontario Gazette. Manitoba has a variation on the collaborative model, which includes both voting members on the rules committee and nonvoting members representing other legal constituencies.

Twenty-five years ago, when Justice Jules Deschenes conducted his study of judicial independence, including in the context of rule-making, he found that, of the $\mathbf{4 5}$ courts he examined, 44 percent could be characterized as "high executive authority," 38 percent could be characterized as "low executive authority" and 18 percent fell into the middle category, which he termed "moderate executive authority."' This likely remains a fair description of the Canadian rule-making terrain.

The implementation of rules is as significant as their development. While the government may have varying roles in the development of court rules, it is judges who interpret and apply those rules, and it is worth pointing out not only that courts will always reserve a measure of discretion to interpret and apply rules of court to achieve the interests of justice, but also that many rules themselves contemplate judicial supervision. For example, the Ontario Rules of Civil Procedure provide that " $[\mathrm{t}]$ he court nay, only where and as necessary in the interest of justice, dispense with compliance of any rule at any time." ${ }^{\text {ts }}$ Thus, even in jurisdictions that may not be categorized as "court-led," judicial control over rules may still be apparent. This will be discussed further below in the context of the inherent powers of the court.

The plurality of forms of rule-making in Canada speaks both to the variety of approaches of court rules and the flexibility engendered by the absence of strong assertions of unilateral constitutional authority by either the executive or the judiciary. As I attempt to clarify the constitutional terrain below, one of two possible implications might arise: first, one or more of the rules committees now in operation infringe the constitutional authority of either the government or the judiciary to control court rules; or second, the constitution does not mandate that either the government or the judiciary need to control some or all court rules. There is a variation on this second option. If control is not constitutionally mandated, does the Constitution require at least that the judiciary and government consult over significant rule changes?

is Jules Deschines, Masters in Their Oun House (Ottawa: Canadian Judicial Council, 1981! (Deschènes Report].

1.. Ontario, Rules of Civil Procedure, r. 2.03. 
It is worth mentioning that there does not appear to be significant unrest from either governmental or judicial quarters regarding the development or application of procedural codes is rare. Governments are unlikely to take strong positions on procedural rules and are even less likely to push through initiatives in this area in the face of judicial opposition, unless significant resource or policy issues are involved. A possible exception to this claim might be the controversy raised by the adoption of mandatory and/or court annexed mediation in several jurisdictions, which some courts have opposed. By contrast, governments are likely to take strong positions and may have the will to proceed without judicial support or involvement when it comes to court fees. It is to this intersection of court rules and core governmental functions such as raising revenue that I now turn.

\section{B. COURT FEES}

Rules committees, as a rule, do not deal with court fees. Fees are dealt with most often as a simple matter of legislative authority and executive policy. They are typically organized in a schedule enacted as a regulation to the civil procedure rules. Fees cover a range of civil litigation instruments, from filing a statement of claim, to motions and examinations, to retrieving a court document from storage. These fees have been increasing in almost every jurisdiction in Canada. For government, they have become an increasingly significant generator of revenue. ${ }^{17}$

Courts generally have been extremely reticent to constrain the government's spending power, including its power to charge user fees. ${ }^{18}$ While it may make sense to reserve a greater role to the executive where the raising of revenue is affected (as with decisions to build new courthouses, adopt new information technologies or other resource intensive issues), there is little in principle to distinguish rules from fees in terms of the core constitutional principles of judicial independence, rule of law, access to justice and the inherent power of a court to control its own process. Where issues of potential disputes between courts, litigants and governments over court administration have arisen, more often than not, fees and revenues are involved.

Court fees in civil matters appear to be on the rise in every jurisdiction. In Alberta, they were recently tripled. The rationale is clear. Governments are cash-strapped and, as Manitoba's Attorney General, Gord Mackintosh, recently observed in relation to a hike in trial fees in that province, "Why should the taxpayer subsidize most of the cost of a private dispute going to trial?"19 Mackintosh added, for good measure, that he hoped the increase in fees would encourage more people to try mediation. Attorneys General around the country, who once championed the courts and access to them at the cabinet table, are increasingly asked to justify public expenditures on courts relative to hospitals, schools and roads. Not only are expenditures under greater scrutiny, but courts are also increasingly viewed as

17 Fees, of course, may also constitule a significant expense for governneents, as government lawyers unust pay these fees unless there is a legislative or regulatory provision exempting the Allorney Gencral from liability for fees.

in See David Mullan. "The Role of the Judiciary in the Review ol Adninistrative Policy Decisions Issucs of L.egality" in Mary Jane Mossman \& Ghislain Otis, eds. The dindicury as Third Bromeh of Government: Manifestations and Challenges to Legitimacy (Montrćal I .es Editions Themis. 2000) 31.3 "New Court Fees Launched" The Lawyers Weekly' (17 September 2004) 2 
potential revenue generators. At a minimum, the civil justice system is expected to operate on a near cost recovery basis. Further, there is a widely held perception that because judicial salaries appear high, courts are well resourced.

In some cases, the modification of court fees is a subject of widespread consultation across an affected court; in other cases, a Chief Justice might be informed of fee increases only days before they are introduced. Even where the judiciary is consulted or given notice of fee increases in advance, it is generally with the understanding that this is a courtesy, or to ensure the government's policy objectives can be achieved, and not because the government believes it has any responsibility or obligation to involve the court in decision-making relating to fees. When called upon to rule on the legality or constitutionality of court fees, however, some judges have subjected fees to surprisingly rigorous scrutiny.

For example, in Pleau v. Nova Scotia (Supreme Cours, Prothonotary), ${ }^{20}$ MacAdam J. of the Nova Scotia Supreme Court ruled unconstitutional a variety of new court fees being introduced in Nova Scotia, including, most controversially, a system of graduated fees that would result in parties paying more in fees for more time in court. In Polewsky v. Home Hardware Store Lid. ${ }^{21}$ the Ontario Superior Court held small claims court fees did not offend any constitutional principle but did find a defect in the inability, under the statute, for a judge to waive those fees where a litigant cannot afford to pay them.

These cases demonstrate the willingness of courts to intervene in executive and legislative policy-making that concerns the courts. The reasoning of the courts in both these decisions is analyzed in the next section, which attempts to map the constitutional landscape of court rules, and to which I now turn.

\section{The Constitutional, LANDSCAPE.}

The Constitution $A C t, 1867^{22}$ does not squarely address the question of which branch of government has primary carriage for court rules. While s. 92(14) of the Constitution Act, 1867 specifically gives to the provinces jurisdiction over "the administration of justice," this only applies to whatever authority is properly legislative (and not judicial) in the first place. In other words, that provision clarifies which level of government has legislative authority over courts, but says little about which branch of government is ultimately responsible for developing and implementing those rules. Even the clarity regarding provincial authority over legislation relating to courts is vitiated to some extent by ss. 96-101 of the Constitution Act, 1867 , which gives the federal government a lead role in judicial appointments to all superior courts and contemplates the creation of federal courts, under which both the Supreme Court and Federal Court of Canada have been established. Today, any approach to the constitutional landscape of court rules must make sense out of federal courts, provincial appellate, superior and provincially appointed courts and in some jurisdictions, municipal courts and the evolving role for justices of the peace, masters and other judicial officers. 
Once again, this diversity militates for a pluralist approach to rule-making structures, but pluralism does not have to be, and arguably should not be, divorced from principle.

Below, I explore a range of constitutional provisions and principles that touch on the rules of court. First, I examine the constitutional principle of judicial independence. This is a wellknown and well-trodden aspect of constitutional law. For the purposes of this analysis, ny interest is in the intersection of administrative independence and the rules of court. As part of this exploration, I examine the inherent powers doctrine, a familiar aspect of the constitutional terrain in the United States and largely uncharted territory in Canada. Second. I consider the emerging constitutional principle of access to justice and the related doctrine of the rule of law.

The backdrop for this review of constitutional principles relating to the rules of court is the broader set of constitutional principles that define the Westminster system of government - principally, the separation of powers, parliamentary supremacy and ministerial responsibility. There is neither the space nor the need to fully explore these constitutional foundations here. ${ }^{23}$ However, these principles raise (at least) two central challenges for judicial control over court rules. First, parliamentary supremacy suggests that courts, even superior courts with inherent jurisdiction, are subject to legislative rule-making, and it is for the goverrment, ultimately, to decide on the kind of civil litigation system that it believes to be in the public's interest. If the threshold for small claims courts, or simplified procedure is to be raised, this argument goes, it is only appropriate for this decision to reside with the government, which has the democratic legitimacy to choose policy preferences and the legislative or administrative form they might take. Even where courts have rule-making authority, this must result from either an explicit or implicit ceding by Parliament of its rulemaking authority to the courts. As the Deschênes Report, Masters in Their Own House asserted of rule-making, "[b]y definition, this is a power delegated by Parliament to the Courts."

This leads to the second challenge, which concerns accountability. Ministers are responsible (in theory, at least) for all acts of the executive. Since virtually all court staff (registrars, clerks, court managers, efc.), except judges, report to the Attorney General, the minister must exercise sufficient control to remain accountable for the performance of court administration. The flipside of this accountability coin, of course, is that judges cannot be directly accountable to the government for court administration. While government in these contexts typically refers just to the executive, and while there is some significant divergence in the dynamics underlying the relationship between courts and the executive on the one hand, and courts and the legislative branch on the other, for the purposes of simplicity in this analysis, I refer simply to control over rules by the court or control over rules by the

3 See Peter W. Hogg, Constitutional lanv of Canada. looseleaf (Toronto: Carswell. 2003).

* Deschenes Report, supra note 15 at 131 . Desclitnes was here referring to the provision of the (riminal Code that expressly gives courts the authority to adopt "rules of court" which govern "pleadings. practice and procedure" and which must be published in the Canada Gazelte. Deschenes goes on 10 observe, however, that, "[t]he legislative power, which delegates this rule making function could, in fact, always make its own legislation on the subject... Nolhing would prevent it from repealing or amending, on its own authority, rules adopted by a court, be if federal or provincial” (ibid. at 132) 
government - whether the government exercises its control by means of legislation, regulation or other government action is not central to this analysis.

It is with these two challenges in mind that I now turn to the two major constitutional principles animating judicial control over court rules: the principle of judicial independence and the principle of access to justice.

\section{A. TIE. DYNamic OF JUIDICIAL INDEPENDENCE}

In this section, I explore the familiar and of litigated doctrine of judicial independence, including the less well explored terrain of the "inherent powers" doctrine, both of which touch on the rules of court.

While the presence and importance of the constitutional principle of judicial independence is beyond dispute in Canada, the source of that authority is neither uniform nor self-evident." Sections $96-100$ of the Constitution $A C t, 1867$ provide for the creation of courts and the appointment of judges, but do not set out limitations on the scope of judicial review, nor provide any mechanism for judicial accountability. Nonetheless, the Supreme Court has interpreted these provisions as implying a regime of judicial independence in Canada. In Cooper v. Canada (Human Rights Commission), ${ }^{26}$ for example, Lamer C.J.C. affirmed that the primary source for the judiciary's independence is ss. 96-100 of the Constitution Act, $1867 .{ }^{27} \mathrm{~A}$ secondary source for judicial independence was found to be the Preamble to the Constitution Act, 1867, which states that Canada is to have a Constitution similar in principle to that of the United Kingdom. ${ }^{28}$ While not necessary to the dispute at issue, in Cooper Lamer C.J.C. proceeded to assert that these provisions of the Constitution $\mathrm{Act}, 1867$ are not merely concerned with judicial independence but also with the judiciary as a constitutionally separate branch of government.

The rationale of and justification for judicial independence is to ensure impartiality in adjudication. ${ }^{29}$ It is a right of the litigant, in other words, not of the judge (individually) or the court (institutionally). ${ }^{30}$ To the degree to which it is perceived that the rules of court are

W.R. Lederman. "The Independence of the Judiciary" (1956) 34 Can. Bar Rev. 769, 1139, reprinted in W.R. Lederman, Continuing Constitutional Dilemmas: Essays on the Constitutional History. Public Lan' and Federal System of Canada (Toronto: Buttenworths, 1981) 109.

[1996] 3 S.C.R. 854 [Cooper].

" Chief' Justice Lamer explained, "Although the wording of this provision suggests that it is solely concerned with the appointment of judges, through judicial interpretation - an important element of which has been the recognition that s. 96 must be read along with ss. 97-100 as part of an integrated whole - s. 96 has come to guarantee the core jurisdiction of the superior courts against legislative encroachment" (ibid. at 871). Ste also Robin Elliot. "Rethinking Section 96: From a Question of Power to a Question of Rights" in Denis Magnusson \& Daniel Soberman, eds., Canadian Constitutional Dilemmas Revisited (Kingston: Institute of Intergovernınental Relations. 1997) 17.

:* Chicf Justice Lamer cited the following passage from Dickson C.J.C.'s reasons in Beauregard v. Camada, [1986] 2 S.C.R. 56 at 72: "Since judicial independence has been for centuries an important principle of the Constitution of the United Kingdom, it is fair to infer that it was transferred to Canada by the constitutional language of the preamble" (Cooper, ibid. at 872-73).

$\therefore \quad$ R. v. Lippé. [1991] 2 S.C.R. 114.

"' Mackin v. New Brunswick (Minister of Finance), [2002] I S.C.R. 405. 
controlled by external forces, even governmental ones, the perception of impartiality of the courts will be affected.

The content of this constitutional principle was set out in Valente, ${ }^{31}$ and consists of three discrete but related forms of protection: security of tenure, financial independence and administrative independence. In Reference re Remuneration of Judges of the Provincial Court of Prince Edward /sland, ${ }^{32}$ the Supreme Court struck down a number of provinces' attempt to curtail or cut the salaries of provincially appointed judges (federally appointed judges have their salary fixed by the federal government). The relationship between the remuneration issue and court rules is explored below. Both areas depend on an understanding of the separation of powers in Canada and the "grundnorm" or judicial independence, which is freedom from political interference or the appearance of it. As Lamer C.J.C. stated, referring to the requirement that the financial security of courts be free from political interference:

These different components of the institutional financial securily of the courts inhere. in my view, in a fundamental principle of the Canadian Constitution, the separation of powers. As 1 discussed above, the institutional independence of the courts is inextricably bound up with the separation of powers, because in order to guarantee that the courts can protect the Constitution, they must be protected by a set of objective guarantees against intrusions by the exccutive and legislative branches of government.

Chief Justice Lamer held that the remuneration of provincial judges could not be subject to government wide cuts because to do so would compromise the independence of the judiciary, contrary to the unwritten guarantee of judicial independence incorporated in Canada through the Preamble of the Constitution Act, $1867 .^{34}$

While security of tenure and financial independence aspects of judicial independence have both a personal and an institutional dimension, the third aspect — administrative independence - only has an institutional dimension. As Lamer C.J.C. stated in the Re Provincial Court Judges, "administrative independence ... only attaches to the court as an institution (although sometimes it may be exercised on behalf of a court by its chief judge or justice)." 35 In Valente, LeDain J. had stated that an "essential condition of judicial independence" was control by the courts over the administrative decisions that bear "directly [and immediately] on the exercise of [the] judicial function." 36 Those types of decisions were described in this way:

Judicial control over ... assignment of judges, sittings of the court, and court lists - as well as the related matters of allocation of court rooms and direction of the administrative staff engaged in carrying out these functions, has generally been considered the essential or minimum requirement for institutional or "collective" independence. ${ }^{37}$

\section{Supra note 3.}

[1997] 3 S.C.R. 3 [Re Provincial Courl Judges].

Ibid. at para. 138 .

Ibid.

Ibid. at para. 120.

Valente, supra note 3 at 708.

Ibid. at 709 . 
While it is difficult to construe court rules as not bearing directly on the adjudicative function, the more compelling argument may be that court rules are not administrative at all. Arguably, however, to the extent that the rules of court impinge on judicial functions, and assuming these are imposed by the legislature or executive rather than developed with or by judges, than this interferes with judicial independence. On this reasoning, however, most of the civil procedure codes in Canada and virtually all of the court fees regimes, are constitutionally vulnerable. Chief Justice Green recently faced a similar conceptual dilemma in a case that raised whether all court staff must be under the direction and control of the judiciary to comply with the constitutional requirements of administrative independence for courts. He sidestepped the dilemma in the following fashion:

It is not necessary to altempt to define the outer parameters of adninistrative independence as it relates to the direction and control of court staft. It is sufficient, for the purposes of this casc, to recognize that some administrative functions performed by court staff are protected. by the constitutional principle of judicial independence, from interference from outside the judiciary. To that cxicnt, the principle of judicial independence ensures that direction and control over court statf for such purposes is exercisable by the judiciary and no one else. ${ }^{38}$

Similarly, I would assert that, leaving aside the outer boundaries of the territory, at least some court rules that go to the heart of adjudication (for example, rules which limit or modify the discretion of the Court to identify and remedy abuse of process or core components of judicial discretion) fall into a protected sphere of judicial independence. Or, put differently, it is difficult to see how they would not when one considers the constitutional principle of judicial independence and the logic of Valente in isolation. When one views this principle as in tension with the principles of Parliamentary supremacy and ministerial responsibility, however, the case for full judicial control resonates less and the case for constitutional accommodation is apparent.

Judicial independence, then (including administrative independence) operates to "insulate the courts." ${ }^{39}$ That insulation, however, also removes any possibility of traditional. democratic accountability for the governance of courts and those aspects of court administration entirely under judicial control. This is not to suggest that those traditional forms of democratic accountability are themselves effective (for example, ministerial responsibility for courts is already compromised by the perceived conflict of the Attorney

Newfoundland and Labrador Association of Public and Prwate Employees $v$. Newfoundland and Labrador (Mfinister of Justice) (2004), 237 Nnd. \& P.E.I.R. 94 at para. 128 [emphasis in original] [NAPE]. See also the Ontario Court of Appeal's approach to the scope of judicial independence in relation to whether judicial secretaries could be unionized: "There can be no question that judges" secretaries perform vital and essential tasks with respect to the administration of justice. It is diffieult to imagine the performance of the judicial role without theit invaluable support. It was therefore manifestly appropriate that in OPSEU $v$. The Crown, supra. the OLRB described their services as essential to the proper administration of the courts" (Ontario (A.G.) v. Ontario Public Service Employees Union (2000), 52 O.R. (3d) 77 at para. I4 (C.A.) (Onsario v. OPSEU)). I sec nothing inherent in the concept of judicial independence that entitles the judiciary presumptively to deprive employees with whom it works of the right to union membership. There may be rare instances where such membership collides with judicial independence, but this case falls far short of any of the principles set out in Maniroba Provincial Courl Judges fssociation v. Maniroba (M/inister of Justice), [1997] 3 S.C.R. 3; and l'alente, supra note 3.

Re Provincial Court Judges, supra notc 32 at para. 130. 
General being a central litigant before the courts), nor that courts cannot be accountable to commissions, intermediating bodies or other institutional representations of the public interest. In any event, it is daunting if not impossible to reconcile direct accountability to what Lamer C.J.C. referred to in the Re Provincial Court Judges as the threat of interference from "the public generally."

The high water mark of separation of courts from public accountability is the notion of the courts possessing "inherent powers" to control their own process and to be insulated from dependence on "an extrinsic will.".40

\section{INHERENT POWERS}

An aspect of judicial independence I wish to highlight in relation to court rules is the more specific doctrine referred to as the "inherent powers" doctrine. This doctrine does not contemplate judicial control over court rules in Canada but I believe provides a helpful window into how judicial control over rules may be elevated to a constitutional concern. This doctrine is typically understood as uniquely American, which provides courts with an inherent right to direct and control any aspect necessary to carry out the judicial function (from budgets to personnel) and rules. Felix Stumpf describes the doctrine in the following terms:

The doctrine of inherent power runs essentially as follows: the courts are a constitutionally created branch of government whose continued effective functioning is indispensable; performance of that constitutional function is a responsibility committed to the courts; this responsibility implies the authority necessary to carry it out; therefore the courts have the authority to raise money to sustain their essential functions. (Hazard. MeNamara and Sentilles. "Court Finance and Unitary Budgeting." 81 Yale 1.J. 1286. 1287 (1972))"

The traditional view is that the inherent powers doctrine has no analogue in Canada. ${ }^{\text {t2 }}$ Stumpf himself noted, "the doctrine is uniquely American; it has no counterpart in England, which has no written constitution or separation of powers." ${ }^{\text {"43 }}$ Of course, Canada now has a written constitution and arguably an increasingly refined doctrine of separation of powers. For this and other reasons, the courts appear less reticent to explore the contours and implications of inherent powers in the Canadian context. However, while the doctrine has arisen most often in American state courts in the context of budgetary disputes, it has emerged in Canada as a residual category governing cour practice and the conduct of proceedings. In $R$. v. Felderhof, the Ontario Court of Appeal confirmed the wide ambit of judicial authority over the courtroom, including the conduct of a trial. As Rosenberg J.A. observed:

Sec Smith v. Miller 384 P.2d 738 at 741 (1963), discussed in Carl Baar, "Judicial Activism in Statte Courts: The Inherent Powers Doctrine" in John C. Gatsley. Inhere'ne Powers of fhe Court (Reno. The National Judicial College, 1980) I. Judicial Collegc, 1994) at 4.

*: Perry Millar \& Carl Baar. Judicial Admimistration in Canada (Kingston and Mfontreal Tlic Institule ol Public Administration of Canada/McGill-Queen's Universily Press. 1981)

3. Stumpf, supra note 41 at 6

4 (2003). 68 O.R. (3d) 48 I (C.A.). 
Whatever may have been the case in the past, it is no longer possible to view the trial judge as litle more than a referee who must sit passively while counsel call the case in any fashion they please. Until relatively recently a long trial lasted for one week, possibly iwo. Now, it is not unusual for trials to last for many months, if not years. Early in the trial or in the course of a trial, counsel may make decisions that unduly lengthen the trial or lead to a proceeding that is almost unmanageable. It would undermine the administration of justice if a trial judge had no power to intervene at an appropriate time and, like this trial judge, after hearing submissions, make directions necessary to ensure that the trial proceeds in an orderly manner. I do not see this power as a limiled one resting solely on the courn's power to intervene to prevent an abuse of its process. Rather, the power is founded on the court's inherent jurisdiction to control is own process. ${ }^{4}$

Justice Rosenberg proceeded to affirm that statutory courts, such as a provincial offences or municipal court, also have the implied power to control their own process. ${ }^{46}$ of course, a judge's inherent power to control process is not the same as an inherent powers doctrine in the American sense of the term. There is no necessary connection between controlling process and controlling resources. This does not suggest, however, one more aspect of court rules that lay outside the province of the executive to unilaterally determine. In light of the discussion above, it is clear that court rules that impinge on adjudicative independence or that interfere with a judge's control of her or his own "process" may be vulnerable to challenge or non-enforcement. However, while much of court administration may appear outside the sphere of these doctrines (human resources policy in a registrar's office may not bear directly on adjudication), most of the rules of court do shape and constrain a court's process and do bear directly on adjudicative functions. Thus, judicial independence is inextricably linked to many, if not most, rules of court; yet it can it be construed as interference with that independence for a government to pursue a mandate of serving the public interest through reforming judicial processes. Rather than exclude government from the administration of justice, judicial independence, in my view, militates for a requirement of judicial acceptance of significant reform initiatives that bear on adjudicative functions.

\section{B. ACCESS TO JUSTICE AND THE RULE OF LAW}

The concept of access to justice reflects several perspectives on social justice and barriers in the justice system - it has spawned a prodigious literature in Canada and other common law jurisdictions with civil justice systems. ${ }^{47}$ The constitutional principle of access to justice, however, is considerably narrower in scope and of considerably more recent vintage, at least in Canada. In British Columbia Government Employees ' Union v. British Columbia (A.G.), ${ }^{48}$ Dickson C.J.C. outlined the rationale for recognizing the principles of "access to justice" and

Ibid. at para. 40 [emphasis added].

4. Justice Rosenberg relied on R. v. 974649 Ontario Inc., [2001] 3 S.C.R. 575, in which the Supreme Court confirmed the jurisdiction of the Provincial Offences Court of Ontario to grant remedies under S. 24(1) of the Canadian Charter of Rights and Freedoms, Part I of the Constitution Act. 1982, being Schedule B to the Canada Act 1982 (U.K.), 1982, c. 11 [Charter].

For just a sampling, see Mary Jane Mossman \& Heather Ritchic, "Access to Civil Justice: A Review of Canadian Legal Academic Scholarship 1977-1987" in Allan Hutchinson, ed., Access to Civil Justice (Toronto: Carswell, 1990) 53. See also Roderick MacDonald, "Access to Justice and Law Reform" (1990) 10 Windsor Y.B. Access Just. 287; Ian Morrison \& Janet Mosher, "Barriers to Access to Civil Justice for Disadvantaged Groups" in Rethinking Civil Justice: Research Studies for the Civil Justice Review, vol. 2 (Toronto: Ontario Law Reform Commission, 1996) 637. 
the "rule of law" as aspects of the Canadian Constitution entrenched, like judicial independence, both through the Preamble to the Constitution Act, 1867, and implicitly through the Charter. He stated:

So we see that the rule of law is the very foundation of the Charter. Let us turn then to s. 52(1) of the Constitution Acl. 1982 which states that the Constitution of Canada is the supreme law of Canada and any law: that is inconsistent with the provisions of the Constitution is, 10 the extent of the inconsistency, of no force or effect... [l]t would be inconceivable that Parliament and the provinces should describe in such detail the rights and freedorns guaranteed by the Charler and should not first protect that which alone makes it in fact possible to benefit from such guarantees, that is, access to a court. As the Coun of Human Rights truly stated: "The fair, public and expeditious characteristics of judicial proceed ings are of no value at all if there are no judicial proceedings". And so it is in the present case. Of what value are the rights and freedoms guaranteed by the Charter if a person is denied or delayed access to a court of competent jurisdiction in order to vindicate them? How can the courts independently maintain the rule of law and effectively discharge the duties imposed by the Charter if court access is hindered, impeded or denied? The Charter protections would become merely a illusory, the entire Charler undermined. ${ }^{\text {t9 }}$

In that case, the Supreme Court upheld an injunction issued by a trial judge in British Columbia, on his own initiative, barring striking workers from picketing on the courthouse steps and impeding access by the public to the courthouse. In short, the Court held that the rule of law forms the infrastructure of the constitution and that the rule of law is contingent on access to justice, which in turn must presuppose access to courts. The Court in $B C G E U$ made clear that interference "from whatever source" falls into the same category as an infringement of access. In his earlier decision in NAPE v. Newfoundland (A.G.), Dickson C.J.C. had asserted that "[t] he rule of law, enshrined in our constitution, can only be maintained if persons have unimpeded, uninhibiled access to the courts of this country." 1

In NAPE, Green C.J. of the Newfoundland Supreme Court relied on this authority, in part, to justify why, on constitutional grounds, certain court staff could not be permitted to participate in a general public service labour disruption. Chief Justice Green asserted:

Surely, the refusal of cour stafr to perform any of their functions - be it processing files in the Registry, dealing with counsel, attending in court, operating the recording equipment, reproducing and inscribing court orders, or ensuring service and enforcement - is an even greater threat to the ability of cilizens to get access to the courts to have their cases heard than the erection of picket lines which might (or might not) be effective in persuading persons not to attend court. If the staff are not present, the court cannot even open for regular business. The public cannot have, in the words of Chafe "unimpeded, uninhibited access" if the courts are shut down because of a strike. ${ }^{52}$

Are picketers on the courthouse steps, or court staff who walk off the job in a labour disruption, any more a barrier to the courthouse doors than limitations of standing, time. venue or fees? Certainly, far more people are denied access on a continual basis on these 
grounds than those denied access on a temporary basis due to labour disruptions or protests. Is any rule or fee unconstitutional if a persuasive case can be made that it impedes or inhibits access? Does it matter whether the impeding, inhibiting force is a governmental one rather than a union or protesting organization?

In Pleau, alluded to above, MacAdam J. of the Nova Scotia Supreme Court addressed these questions indirectly in the course of elaborating on the relationship between access to justice and court fees in the following terms:

Access to justice is neither a service nor a commodity. It is a constitutional right of all citizens; any impediments must be strictly scrutinized. Regardless of whether the impedimenl takes the form of a tax. a tee, an allowance, or some other form, it will, and must fail if its effect is to unduly "impede, impair or delay access 10 the courts. 53

Later in the same judgment, MacAdam J. returned to this theme and observed the following:

liecs that late an incidental, but real, effect on access to the courts or justice may have as much impact on access as fees directly related to the judge or the court's time. Here the Hearing Fee is structured on the use of facilities and staff but direetly relates to the accessibility of the judge. Fees related to the provision of services, sucli as for the commencement of a legal proceeding, setting down for trial, as a penalty for wastage of resources caused by latc trial adjournments and for summoning juries involve the processes in geting to trial or to the court and providing they are not so inordinate as to effectively "impede, impair or delay" access to the courts, the provisions of the Act permit them and nothing under the Constitution, both written and unwritten, preclude them. ${ }^{\text {s4 }}$

Of course, this constitutional principle must include a balance, an appreciation of the legitimate interest of the government in recovering a portion of the outlay in providing court services and the limiting effects of socioeconomic inequality on access to justice. As Lambert J.A. noted in John Carten Personal Law Corp. v. British Columbia (A.G.), ${ }^{55}$ in which filing fees were unsuccessfully challenged:

There are many reasons why the cost of legal services, or a lack of funds, may restrict, hamper, or even prevent a persen from exercising rights of access to the courts or rights of access to other legal services. What would be required in order to find this Act [Social Services Tax Act] wholly unconstitutional, or even unconstitutional in its application to a particular casc, would be proof that people, or a class of people, in general, or some person in particular, who would have been able to exercise the legal rights in question if this tax were not in effect, were or was prevented by this tax from exercising those rights... What would be required would be proof that the right was denied, or its exercise was prevented, by the existence or operation of this tax. In other words, that a right which would have been exercised but for this tax could not be exercised because of this tax. ${ }^{36}$ 
This line of reasoning can take the search for an appropriate balance in one of two directions: either fees should be income contingent so that everyone's financial burden remains proportional to their ability to pay (and where one has no ability, presumably one would have no burden); or a court must have the discretion to waive fees in particular cases of hardship. Both of these policy responses to the problem of access raise the legal question of how to distinguish a reasonable from an unreasonable fee (and also raise the issue of what a court can and should do if it concludes that a fee is unreasonable).

A "reasonable fee," defined, however, cannot be said to infringe access to justice. But what is "reasonable" goes, of course, to the heart of the access principle. Should it be proportional to wealth or income, should it be left to judicial discretion, should it differ according to the gravity of the matter or should it "float" according to a range of factors in the fashion of costs awards? Justice MacAdam grappled with this issue to some extent in Pleau and concluded in a somewhat circular fashion:

A reasonable fee is neither an impediment, impairment or cause for delay. A reasonable fec, however, is not necessarily a full reimbursement for the costs of the services. In many cases, it will be substantially less than the costs of the services. Otherwise valid reasonable fees, will lose their constitutional validity, in circumstances that cause them to "impede, impair or delay" access to the courts. ${ }^{57}$

The question of fees and access to justice was also the subject of the judgment in Polewsky, referred to above. ${ }^{58}$ Polewsky involved four separate actions in the Small Claims Court, each of which required $\mathrm{Mr}$. Polewsky to pay the $\$ 50$ fee required to file his claims. In one of those actions, he brought a motion seeking a waiver of the fee required to have his actions placed on the trial list. Deputy Judge Shields granted this motion, ${ }^{39}$ in part based on an affidavit indicating that legal aid was not available to a litigant in Small Claims Court. Subsequently, a series of similar motions were heard by Gillese J., who found that in the absence of an express statutory power to waive fees, a Small Claims Court judge has no jurisdiction to do so. On the constitutional issue, she held that there is no constitutional right of unimpeded access to the civil courts and that the fees do not violate s. 15 of the Charter. since poverty is not an analogous ground under s. 15(1). She further found, in obiter, that s. 7 of the Charter would also provide no redress in these circumstances. The Divisional Court upheld the ruling of Gillese J. with respect to her interpretation of the statute and her rulings on the Charter. The Divisional Court accepted, however, a common law right of access to justice applied to these circumstances, relying in part on Witham. ${ }^{60}$

Plean, supra note 20 at para. 105. This passage is similar to one in $R$. v. Lord Chancelor, ex parte Witham, [1997] 2 All. E.R. 779 (Q.B.) [Witham] where the Court held "It]he selting of reasonable court fees of general application does not constitute interference with an individual's right of access to the court. Whether court fees are set at a reasonable level is a separafe question from whether it is appropriate for a particular individual, having regard to his financial and other circumstances, to be given financial assistance in respect of some or all of those fees and whether such an individual will be denied effective access to the courts in the absence of such assistance" (Withom, ibid. at 783 [cmphasis in original]).

s* Polewsky, supra note 21 .

3. Polewsky v. Bank of Montreal, [1999] O.J. No. 2606 (Gien. Div.) (QL).

(til Sec also R. v. Secretary of State for the Home Department and others, ex parte Saleem, [2000] 4 All E.R. 814 (C.A.). 
The Divisional Court held that a citizen's right to access to the courts to enforce his or her civil rights is a common law constitutional right that can only be abrogated by clear and express statutory language, though that right of access was held "subject to the caveats of merit and proof of indigence." ${ }^{" 61}$ The Court in Polewsky nonetheless affirmed, as in Pleau, that in Canada, "quite apart from the Charter, there is at common law a constitutional right of access to the courts." 62 The Court linked this constitutional principle of access directly to the court's guardianship function over the rule of law, which, as the Court notes, both stands independently of the Charter and at the same time provides a foundation for the Charter. The Court concluded:

We agree that the Rule of Law infuses this court's determination of the issues raised in this appeal. We say that the existence of the Rule of Law combined with what we find to be the common law constitutional right of access to justice compeis the enactment of statutory provisions that permit persons to proceed in forma pauperis in the Small Claims Court. ${ }^{63}$

In the result in Polewsky, while the Court effectively ordered the Ontario Government to legislatively provide for a discretion to waive fees in the case of indigent litigants, the Court applied a "but for" test to the actual circumstances of the case before it and concluded that Mr. Polewsky had not demonstrated that his access to the Small Claims Court would be impeded but for a waiver or reduction of fees. ${ }^{.4}$ In other words, had such a discretion been available, the Court would not have exercised it in favour of Mr. Polewsky, resulting in a pyrrhic victory at best for his personal crusade against court fees.

The connection between access to justice and an indigent's ability to afford litigation has also received recognition from the Supreme Court. In the recent case, British Columbia (Minister of Forests) $v$. Okanagan Indian Band, ${ }^{\text {os }}$ the Court affirmed a trial judge's discretion to provide interim costs to an impecunious litigant in advance of a proceeding if it would not otherwise be possible for the litigation to go forward. On the subject of the costs rule, Lebel J. observed:

Another consideration relevant to the application of costs rules is access to justice. This factor has increased in importance as litigation over matters of public interest has become more common, especially since the advent of the Charter. In special cases where individual litigants of limited means seck to enforce their constitutional rights, courts often exercise their discretion on costs so as to avoid the harshness that might result from adherence to the traditional principles. This helps to ensure that ordinary citizens have access to the justice system when they seek to resolve matters of consequence to the community as a whole. ${ }^{66}$

a) Polewsky, supra note 21 at para. 60 .

G. Ibid. at para. 62.

a) Ibid. at para. 76.

it Sbid., relying on other instances of such a "but for" analysis: Alles v. Maurice (1992), 5 B.L.R. (2d) 146 (Ont. Gen. Div.); Organ v. Barnell (1992), 11 O.R. (3d) 210 (Gen. Div.); Leopold v. Leopold, [200I] O.J. No. 3355 (Sup. Cl.) (QL); and Waxman v. Waxman (2003), 30 C.P.C. (Sth) 121 (Sup. Cl. J.). [2003] 3 S.C.R. 37 ].

w. Ibid. at para. 27. The Court made the interim costs award subject to a set of criteria:

There are several conditions that the case law identifies as relevant to the exercise of this power, all of which must be present for an interim costs order to be granted. The party seeking the order must be impecunious to the extent that, without such an order, that party would be deprived of the opportunity to proceed with the case. The claimant must establish a prima facie case of sufficient 
While the right of access to justice and the judicial role in safeguarding that right are now well recognized in Canadian constitutional law, it is unclear from Pleau and Polewsky whether this right is only a negative one (in other words, one in which legislative provisions or government acts that impede access may be challenged and invalidated in court) or also a positive one (in other words, one in which government must proactively ensure access to the courts).

In light of the recent case law, should we approach access to justice the way we do judicial independence and look to "objective guarantees" such as independent commissions to also take responsibility over setting court fees? Or should we approach the question as one integrated with court rules generally, so that rules committees or other collaborative bodies should have control over or at least a veto function in relation to fees? Or finally, is the right approach simply that courts have the authority and responsibility to subject those fees to scrutiny, where challenged, and to rule accordingly on a case-by-case basis? Should government remain free to set fees as it wishes (subject to Eurig Estate $(R e)^{67}$ and other constitutional constraints)? If we conclude that judicial input or control is required on the question of fees on the grounds of access, then how can we distinguish fees from the funding for legal aid programs, or the capital investment in courthouses and court administration generally. Once again, this leads us to a question of boundaries, and to the simple question with which we began - when it comes to the rules of court, where do the legislative, executive and judicial roles and responsibilities begin and end? It is to elaborate on this answer that, by way of conclusion, I now turn.

\section{The Theory and Practice of Constitutional Accommodation}

I wish to suggest that a framework of constitutional compromise and institutional interdependence is the most effective mechanism for (avoiding and) resolving potential disputes involving court rules and fees that otherwise could threaten the integrity and viability of the administration of justice. Such a framework requires surmounting a thin or superficial view of separation of powers and viewing the key principles at stake, such as Parliamentary supremacy, ministerial responsibility, judicial independence and access to justice as complementary.

In the past, calls for collaboration (there have been many) have usually boiled down to proposals for advisory committees or management boards composed of some collection of judges or judicial designates, politicians or political designates, civil servants and occasionally members of "stakeholder" groups. There are several of these collaborative committees in existence in Canada - one of the longest running and most successful is the Manitoba Court Executive Board - although few have any real decision-making power. Ireland has adopted a more robust version of this model for a range of court administration - the Board of the Irish Court Service consists of eight judges (including four chief justices/court presidents or another judge they nominate; three judges from each court below

merit to wartant pursuit. And there must be special circumstances sufficient to satisfy the cour that the case is within the narrow class of cases where this extraordinary exercise of its powers is appropriate (ibid. at para. 36). 
the Supreme Court, each one elected by judges of their court; and one judge nominated by national Chief Justice) and eight non-judges (including three nominated by the Ministry but only one from within the Ministry, one CEO of Courts Service, one member of Courts Service staff elected by staff, one barrister nominated by Chair of the Bar Council, one solicitor nominated by the President of the Law Society of Ireland and one nominee of the Irish Congress of Trade Unions).

While the Deschênes Report, ${ }^{68}$ the Zuber Inquiry, ${ }^{69}$ the Blair Civil Justice Review ${ }^{70}$ and other studies have all recommended collaborative boards and councils of varying sizes, dimensions and responsibilities, perhaps the best known example of an aspiration for a similar sort of body in Canada emanated from Martin Friedland's landmark study $A$ Place Apart: Judicial Independence and Accountability in Canada." While this study does not deal with the rules of court per se, Friedland argues for a Board of Judicial Management that would function much like the governing council of a university, with appointments coming not just from government and the judiciary but from the law society, bar association and law deans.

Whatever might be the merits of managing courts by committee, and with the evident success of rules committees across various jurisdictions in Canada, my interest here is not in the institutional forms of collaboration but rather in the institutional forms for resolving the constitutional dilemma raised by a shared role in rule-making between government and the courts, although these are clearly interrelated issues. What is glaringly absent from the terrain of rule-making in Canada is a credible forum for resolving disputes between government and courts (which would also have a strong dispute avoidance function. While such a dispute resolution entity could take several forms, the most familiar and palatable form would likely be an independent commission.

One cannot raise the possibility of a commission to address disputes between the government and the courts without dealing with the now significant adversarial baggage accumulated from a decade of litigation over the issue of judicial remuneration. While these independent remuneration commissions serve a different purpose (that of setting salaries prospectively rather then resolving disputes retrospectively), they engage similar issues in terms of the search for a body and a process that is compatible with judicial independence while not usurping the legitimate role for government in setting its fiscal and policy priorities in a manner of its choosing. Below, 1 look more closely at the remuneration litigation in order to determine whether the commission model is well-suited to the context of rule-making, and if so, how its form and mandate should be crafted. 


\section{A. TIIE Final ARBITER? CONSTITUTIONAL ACCOMMODATION THROUGH REMUNERATION COMMISSIONS ${ }^{72}$}

As the Supreme Court established in the Re Provincial Court Judges, the constitutional principle of judicial independence requires that the setting of judicial salaries be undertaken by independent remuneration commission. ${ }^{73}$ However, to reconcile this practice with the policy demands of government, the Court provided a mechanism for the government to modify or reject the recommendations of these commissions. The courts' involvement in resolving disputes over judicial independence raises the possibility of inherent conflicts of interest. Nowhere is this more apparent than in the realm of financial independence. Allocating funds to public goods, services and programs typically is a matter for political judgment and outside the sphere of judicial involvement. ${ }^{74}$ Allocating funds to courts and judicial salaries represents an important exception to that rule. The Court reviewing the government's justification for rejecting or modifying a judicial compensation commission's recommendation is to defer to the government on a standard of "simple rationality." Chief Justice Lamer, writing for the majority in the Re Provincial Court Judges, introduced this standard and distinguished it from the s. I standard under the Charter in the following way:

The standard of justification here, by contrast, is one of simple rationatity. It requires that the governinent articulate a legitimate reason for why it has chosen to depart from the recommendation of the commission. and if applicable, why it has chosen to treat judges differently from other persons paid from the public purse. $A$ reviewing court does not engage in a searching analysis of the relationship between the ends and the means. which is the hallmark of a s. I analysis. However, the absence of this analysis does not mean that the standard of justification is ineffectual. On the contrary, it has two aspects. First, it screens out decisions with respect to judicial remuneration which are based on purely political considerations, or which are enacted for discriminatory reasons. Change to or freezes in remuneration can only be justified for reasons which relate to the public interest, broadly understood. Second, if judicial review is sought, a reviewing court must inquire into the reasonableness of the factual foundation of the claim made by the government, similar to the way that we have evaluated whether there was an economic emergency in Canada in our jurisprudence under the division of powers. ${ }^{75}$

As has become clear in subsequent litigation on the meaning of this standard, simple rationality is anything but simple. ${ }^{76}$ During this term, the Court granted leave to perhaps the

7 Portions of this analysis are drawn from "Developments in Administrative Law: the 2002-2003 Term" (2003) 22 Sup. Ct. L. Rev. (2d) 21.

3) Typically, these commissions follow a tripartite labour arbitration model, where one member of the commission is chosen by the govemment, one member by the judiciary and a chair appointed jointly by the other two.

74 See Geoffrey Cowper \& Lorne Sossin, "Does Canada Need a Political Questions Doctrine?" (2002) 16 Sup. Ct. L. Rev. (2d) 343.

is Re Provincial Court Judges, supra note 32 at para. 183.

7. Sec e.g. Re Brilish Columbia Legislative Assembly Resolution on Judicial Compensation (1998). 160 D.L.R. (4th) 477 (B.C.C.A.); Alberta Provincial Judges' Assn. v. Alberia (1999), 237 A.R. 276 (C.A.) [Alberia Provincial.Mdges'Assn.]: Newfonndland Assn. of Provincial Court Judges v. Newfoumdland (2000), 192 Nfld. \& P.E.I.R. 183 (Nfld. C.A.); Conferencu des juges du Quebec c. Québec (P.G.) (2000). 196 D.L.R. (41h) 533 (Que. C.A.) [Conférence de juges du Québec]: Maniroba Provincial Judges 'Assn. v. Manitoba (Minister of Justice) (2001), 202 D.L.R. (41h) 698 (Man. Q.B.) [.Manifoba Provincial Judges 'Assn. ]: Ontario Judges' Assn. v. Ontario (Managemem Board) (2002), 58 O.R. (3d) 186 (Div. Ct.) [Ontario Judges $^{\circ}$ Assn.]; Bodner v. Alberla (2002), 317 A.R. 112 (C.A.) [Bodner]; 
most contentious dispute involving this standard in Bodner $v$. Alberra. "What follows are some preliminary thoughts on the challenges posed by Bodner and its sister litigation to the Court's evolving understanding of deference.

In Bodner, the second major litigation arising from Alberta in the wake of the $R e$ Provincial Court Judges, ${ }^{78}$ the Alberta Court of Appeal upheld a decision of the trial judge that the refusal of the Alberta Government to implement recommendations of a judicial compensation commission on salaries for justices of the peace failed to meet the standard of "simple rationality." Justice Paperny, writing for the majority of the Court of Appeal, described this standard of justification as follows:

[T]he standard of justification for rejection must be congruent with the constitutional purpose of a commission.

This means that before government can constitutionally resort to its power to reject, it must first demonstrate that extraordinary circumstances of sufficient importance or significance exist. Having done so, the reasons must then pass the test of rationality in this constitutional context: they must be reasonable, their factual foundation must be reasonable, they cannot be utilized as a means of economic manipulation and they must have a rational connection to the circumstances alleged. ${ }^{80}$

The Alberta Court of Appeal's Iwo-pronged approach to justification (first demonstrating extraordinary circumstances and second demonstrating that the government's response is reasonable) failed to persuade the New Brunswick Court of Appeal, which held that the "simply rational" standard implied a more deferential degree of scrutiny.

In New Brunswick Provincial Judges' Association, ${ }^{81}$ the Court of Appeal found no basis on the "simply rational" standard to interfere with the Government's decision to reject the recommendations of a salary commission. Justice Robertson, writing for the Court in the New Brunswick Provincial Judges' Association case, said of this issue, "In summary, the understanding that a government cannot depart from a salary recommendation without first

Provincial Court Judges' Assn. of New Brunswick v. New Brunswick (A Iimister of Justice) (2003), 260 N.B.R. (2d) 201 (C.A.) [New Brunswick Provincial Judges" Assn.].

Ibid. This appeal is discussed in Kenneth Lysyk \& Lorne Sossin, "Judges" in Kenneth Lysyk \& Lorne Sussin, eds., Barristers and Solicitors in Practice, looseleaf (Toronto: Butterworths, 1998) 11.01.

The first litigation resulted from the Alberta Government's rejection of salary recommendations made by a salary commission in June of 1998 on the grounds that other public servants in Alberta had had their salaries teduced or frozell over the period in whiclt the commission liad recommended judges receive a salary incrense. 'Tlie government's response was upheld in Alberta Provincial Jidges 'Assn., supra note 76, leave to appeal to the S.C.C. denied, [2000] I S.C.R. xviii.

A salary commission was established in 1999 to deal with the salaries of justices of the peace. It issued a report on 29 February 2000, proposing substantial increases. Before then, the salary of justices of the peace in Alberta had remained at $\$ 55,008$ since 1991 and the commission recommended increasing them to $\$ 95,000$ in 1998, $10 \$ 100,000$ in 2000 and $\$ 105,000$ in 2002. On 17 May 2000, the Crown rejected the recommendation on salary. modified the recommendations on annual increases and accepted the balance of the recommendations. The reasons for rejecting the recommendations were that the proposed increases, ranging from 73 percent to 173 percent depending on the classification of justices of the peace, were excessive when compared to increases in other funded programs. The government also argued that the commission had erred on crucial elements. While the trial judge accepted that the commission had erred in some respects, the justification offered by the government for rejecting the commission's recommendations was found not to meet the "simply rational" standard and were declared invalid. See Bodner v. Alberia (2001), 296 A.R. 22 (Q.B). 
satisfying an 'an exceptional circumstances' test has, in my respectful view, no foundation in law." 82 Justice Robertson also disagreed with the majority view in the Alberta Court of Appeal that the "simply rational" standard required a "thorough and searching examination of the reasons proffered" and that this standard "is not easy to achieve." In his view, the Alberta Court of Appeal in Bodner had deferred to the judicial compensation commission rather than to the government, as Lamer C.J.C. had intended in the Re Provincial Court Judges.

In addition to Alberta and New Brunswick, Ontario, ${ }^{84}$ Manitoba ${ }^{95}$ and Quebec ${ }^{86}$ have also witnessed significant litigation between judicial associations and provincial governments over the "simply rational" standard. A consensus on how courts should approach the delicate relationship between the demands of judicial associations, the policy preferences of provincial governments and the expertise of compensation commissions has yet to emerge. Even where the consensus appeared settled, as in the case of Ontario's commission's recommendations on salary, which are by statute binding, litigation has emerged in the face of salary awards perceived as out of line with fiscal reality. ${ }^{87}$

Moreover, it is becoming increasingly difficult for the reviewing courts themselves to remain above the fray. This is illustrated by the aftermath of Bodner. Following the Alberta Court of Appeal's decision, which resulted in an order that the Alberta Government pay to the Justices of the Peace benefits totaling $\$ 3.2$ million, the Government brought a motion to the Court for a stay of the order pending its appeal to the Supreme Court of Canada. The Government indicated in its submissions that if it were forced to pay the monies ordered by the Court of Appeal immediately, those funds would have to be taken out of the court services budget (which funds, among other items, the courthouse facilities and resources used by superior and appellate judges in Alberta). Justice Paperny draws from the Government's position the following conclusion:

In justifying the first proposition (that the government must satisfy the conmission's recommended salary increase from the court services budget]. Hhe government affidavit states that Justice is going through a period of economic restraint. Why this is so is unclear. As discussed above, the government offers no evidence why the judgment cannot be paid from general government reserves... In the absence of a legitimale ralionale for this position. a reasonable person might conclude that its purpose or efiect was to apply pressure to the decision maker, in turn, casting doubt on its impartiality... The public perception of judicial independence is of utmost importance. Confidence in our judicial system is fundamental to democracy. If a court is perceived to be subject to financial sanction for the decisions it makes, public confudence will, justifiably, be diminished.

Lid at para. 119

n' $\quad$ bid. at para. 115 .

ws Ontario Judges Assn, supra note 76.

". Maniroba Provincial Judges 'A.ssn., stupra note 76.

*. Conférence des juges du Québec, supra note 76. Sec also Confiruncess des juges du Québec c. Québec (P.G.), [2003] R.J.Q. 1488 (C.S.): Minc c. Québec (P.G.), [2003| R.J.Q. 1510 (C.S.), in which the Quebec Court of Appeal's approach has been applied and extended.

* Ontario Conference of Judges v. Ontario (Managemem Boarh) (2004). 188 O.A.C. 244 (Sup. C1 1.$)$ (government's argument on jurisdictional grounds based an commission's failure to consider Onlario's deficit position was rejected on procedural grounds as goverument had not exhausted its remedits. government chose not to appeal the decision). 
Where the court is faced with the loss of services to it, if it fails 10 grant the order requested, it is reasonable to conclude that public trust in institutional impartiality is adversely affected. ${ }^{88}$

Consequently, Paperny J.A. concluded that she had to recuse herself from deciding on the question of the stay and left this for the Supreme Court to consider as well when it hears the appeal in Bodner.

While it may be accurate to say that the compensation commission's recommendations are not "binding," it is equally accurate to say that they are not merely "advisory" either. The search for the reasonableness of a government's departure from commission recommendations requires scrutiny of the reasons offered by that government and the connection between those reasons and the facts and evidence on the record. This strikes me as fundamentally distinct from the review of legislation under the division of powers, where governments are neither required nor expected to provide "reasons" for their legislative acts. As framed in Bodner, the New Brunswick Provincial Judges' Association case and others, the issue appears to be whether courts hearing disputes arising from the rejection of commission recommendations, by applying the "simply rational" standard, should defer to the provincial government or defer to the commission. This dichotomous approach to judicial independence, in my view, has shown itself wanting. The real problem, I would suggest, is that, save for exceptional circumstances, courts should not be hearing these disputes to begin with.

While the appearance of a conflict may not be as apparent where federally appointed courts are hearing disputes involving provincially appointed judges, this is a thin distinction, especially since provincial governments do not divide their court administration budget into federally appointed and provincially appointed court categories. The spectre of the federal government's rejection of a salary recommendation for federally appointed judges being taken to federal court was raised when the government recently balked at a rumoured 10 percent salary increase recommendation to which MP salaries were linked. ${ }^{89}$ In the end, the government chose to detach MP salaries from the judicial remuneration commission's recommendations and a crisis appears to have been averted. Once again, however, the absence of a mechanism to effectively depoliticize disputes between courts and governments is apparent.

\section{B. CONSTITUTIONAL ACCOMMODATION THROUGH INTERDEPENDENCE.}

In light of the judicial remuneration litigation, and the uncertainty and animosity to which it has given rise, one approach in the area of court rules would be simply to take a clear stance on the final authority of one branch of government. Deschênes, in his report, recommended that "in the area of rules of practice and procedure, all common law jurisdictions should recognize and confer on the judiciary complete authority, without

wh Bodner v. Alberta (2003), 327 A.R. 77 at paras. 27, 29 (C.A.).

": Jeremy Hainsworth "Judges Act headache for PM; Judges await decision on pay increase, but conflict of interest may arise as increase linked to MPs' pay" The Ilamilton Spectator (12 July 2004) A10. 
executive control or veto" 100 and also that legislative provisions conferring on the Lieutenant Governor in Council the exclusive authority to enact rules of practice and procedure should be repealed. While Deschênes adopted a fairly narrow definition of these rules (and distinguished them from the more general rules of civil procedure, although he thought judicial control over these rules should be given "serious consideration" as well)," this recommendation reflected his overarching belief that at the end of the day the administration of the courts should be a matter reserved for the courts. While I tend to agree with this view of the constitutional authority, this does not lead inexorably to the conclusion that decisionmaking over rules, broadly construed, should reside alone with courts to be exercised in isolation from government priorities and preferences.

When one broadens the horizon of court rules to include fees, simplified procedures, mediation, case management and administrative matters that bear directly on the courtroom (as the principles of judicial independence and access to justice suggest we should), the simple approach of judges being "masters in their own house" looks more problematic. It is in these broader areas that courts and governments may most often be divided. Each has tools at its disposal to pursue its vision of court rules. In Ontario, for example, the government introduced mandatory mediation and case management (notwithstanding resistence from the Bar) in order to achieve its policy goals of encouraging settlements and reducing the cost and delay assuciated with lengthy litigation. In November 2004, the Toronto Region of the Ontario Superior Court issued a Practice Direction that significantly curtailed the application of mandatory mediation and case management in Toronto to achieve its policy goal of redressing the civil case backlog and rising cost of litigation in Toronto. ${ }^{92}$

The approach I advocate, thought hardly a solution to all the vexing concerns to which court rules may give rise, is to conceive of court rules along a spectrum - on one end, there are a series of settings where the government may (and should) have ultimate authority to develop and apply certain rules, but where in practice the government's ability to achieve its objectives will depend on meaningful consultation with courts. An example of such an area might be court fees or decisions relating to the design and configuration of courthouses whether a courtroom could be used for a sentencing circle or accommodate video conferencing affects both court rules and governmental resources. On the other end of the spectrum are settings where the judiciary has the final say but where the courts' ability to achieve its objectives may depend on meaningful consultation with the government, especially where resources are involved. An example of this might be organizing the schedule of circuit courts. In the middle of the spectrum is an important and underscrutinized grey zone, where for constitutional and pragmatic reasons, neither side can or should be permitted to trump the other - and where courts and governments are compelled through their mutual

") Deschênes Report, supra note 15 at 132. The focus on common law jurisdictions was in recognition of the different legislative scheme dealing with court rules in Quebec. which recognized the autonomy of the courts in relation to rule-making.

is Jid. at 139

12 Seeonline: Ontario Courts <www.ontariocourts.on.ca/superior_court_justice/notices/casemanagement. htm>. While the government may have fell it was inappropriate for the Coun to vitiate its policy initiative in this fashion, it had few official recourses to raise such a challenge (beyond responding with legislation which purports to overrrule the policy direction). The lack of a dispute resolution mechanism and the availability of the means to stymie if not frustrate each other's goals provides a compelling rationale for collaborative solutions. 
interest in the administration of justice to work together to resolve differences, find compromises and overcome barriers. An example of this might be the decision to adopt court-annexed mediation. All of these areas should be seen as sites of interdependence. Interdependence presupposes a measure of autonomy but also a shared reliance.

A framework of interdependence should not exclude the involvement of other key participants in the justice system. While the Constitution $A c t, 1867$ is silent on the rights of stakcholders to have input into justice system policy, the success of court rules often depends on the perspective of downstream users. Where collaboration is itself constitutionally mandated, or where it is simply desirable, it may be beneficial to include outside groups in the rule-making process. As Lord Woolf observed in his report to the Lord Chancellor on the development of new court rules for the United Kingdom, the inclusion of "consumer" and "lay" advisory input provided a crucial "counterbalance" to the professional legal viewpoint that often dominates rules committees. ${ }^{93}$ Lord Woolf also saw the development of court rules as a reflection of a culture of access to justice - he asserted, "Genuine access to justice requires people to be able to understand how the legal procedure works. The procedure, working properly, is a vital guarantee that justice will be done; that it can be seen to work properly helps to ensure that justice will be seen to be done." ${ }^{14}$ The importance of public confidence in the justice system animates and underlies the imperative that governments and courts treat the rules of court as a joint enterprise.

An interesting example of this collaborative approach was the experience of Ontario with a major overhaul of its rules of civil procedure in the early 1980s. ${ }^{95}$ Now Chief Justice, then Attorney General Roy McMurtry struck a task force in the mid 1970s to review revisions to the court rules, with a clear mandate to simplify the rules, consider alternative, more expeditious and less formal adjudicative procedures and to determine an appropriate method for the continuous review of the rules in the future. In short, the government staked out a policy interest in court reform. The rules committee thereafter considered this initiative and gave its enthusiastic endorsement, assisted by a committee of judges from the then Supreme and County Courts. A broader committee of leading members of the Bar also gave its imprimatur to the initiative and respected academics were retained to provide opinions. A comparative study of other jurisdictions was undertaken. A variety of organizations, both within and outside the legal profession were consulted and invited to make submissions. Draft rules were circulated for comment before advisory committees, who met 31 times during the drafting of the rules. Court staff and registrars were engaged in lengthy discussions to ascertain their perspectives. While this was not a perfect process, it was a largely successful one, which managed to pay fidelity to judicial independence as well as ministerial responsibility, access to justice as well as Parliamentary sovereignty.

" I.ord Woolf. Access to Justice: Final Report to the Lord Chancellor on the Civil Justice System in England and Wales (London: HMSO. 1996).

Jbid. at 272.

"s An account of this process is contained in correspondence between the Chair of the Civil Procedure Revision Committee, Walter Williston to Altorney General Roy MeMutry (4 February 1980), reprinted in Walter Williston, Civil Procedure Revision Commintee (Toronto: Ministry of the Attorney General, 1980). 
The constitutional imperative of collaboration may lead to a variety of institutional forms. The litmus test is whether both governments and courts have confidence in the process. This is, I believe, where the judicial remuneration process has become unduly rigid and where the rules development process has remained flexible. Nonetheless, flexibility cannot be a substitute for constitutional principle. What I suggest here is that the existence of an independent commission of the courts, or some analogous non-judicial, non-governmental body to which disputes between government and courts can be brought (and perhaps even references to clarify constitutional boundaries), would go a long way to allaying the tensions that now animate disputes over some court fees and rules innovations. Such a body would be able to mediate and communicate the shared guardianship of the courts and government over, among other principles, access to justice. At the end of the day, the justice system rises or falls not simply on the diffuse notion of public confidence in the administration of justice or respect for the rule of law but rather on the lived experience of litigants, judges, lawyers and court staff. The integrity and aspiration of our justice system is contained in its rules and practices; the constitutional principles discussed above make collaborative approaches to those rules and practices both possible and necessary. 